\title{
Users' perceptions and willingness to pay in interurban toll roads: identifying differences across regions from a nationwide survey in Spain
}

\author{
Juan Gómez \\ Anestis Papanikolaou \\ José Manuel Vassallo
}

\begin{abstract}
Users' acceptability is considered one of the key drivers for the successful implementation of transport policy measures. This is especially crucial in the case of toll roads since they are financed through drivers' contributions. Previous literature in this field has mainly focused on measuring users' attitudes towards urban congestion pricing strategies. However limited research has been developed concerning interurban toll roads. Previous research shows that socioeconomic variables are not conclusive to explain users' perceptions towards tolls. By contrast, other drivers such as regional differences seem to play a more important role, especially when charging conditions within the same nation greatly vary across regions. This paper analyzes regional differences in users' attitudes within an asymmetrical distribution of the toll road network across regions. Based on a nationwide survey conducted to road users in interurban toll roads in Spain, we develop both a binomial logit and a censored regression (tobit) model to explore drivers' perceptions and willingness to pay. The research concludes that users from regions with a more extensive tolled network generally show a more negative attitude towards charges, but not necessarily a lower willingness to pay. The paper also points out that an asymmetrical distribution of toll roads across regions may result in negative perceptions among those users perceiving to be unfairly treated when compared to citizens in other regions.
\end{abstract}


Keywords Users' perceptions - Willingness to pay · Toll roads · Logit model · Tobit model $\cdot$ Spain

\section{Introduction}

Budgetary restrictions faced by national governments in the last decades have led them to limit their expenditure in public policy priorities, such as road infrastructure, and seek alternative funding mechanisms. As a result, tolls and road user fees have increasingly become a common option to collect stable resources for funding road projects (Matas and Raymond 2003), both in the United States and many European countries. Road charging represents a powerful means to raise funds, but may also change travel conditions and users' choices in the transport network. In this respect, it is generally agreed that users' acceptability is one of the key drivers to achieve a successful transport policy (Kockelman et al. 2009), especially when it comes to road pricing strategies. Policy makers must seek to recommend options that not only have strong public support, but are also desirable in terms of equity, ability to generate stable revenues, capacity to encourage environmentally responsible choices, etc. (Dill and Weinstein 2007).

Despite the increasing literature on attitudes towards tolls and acceptability of road user charges, several research gaps can be identified. Firstly, there is limited previous research focusing on interurban contexts, what contrasts with the broad literature on urban areas. Secondly, stated-preference surveys on free roads are often employed, with a limited usefulness since potential users are asked about choices they may have not experienced or are not easy for them to imagine (Odeck and Kjerkreit 2010).

Existing literature on users' perceptions towards tolls has traditionally analyzed the influence of socioeconomic factors (age, income, trip purpose, etc.), but has not generally got to conclusive and coincident results about their influence on attitudes (Yusuf et al. 2014). Additionally, some authors (Rienstra et al. 1999; Schade and Schlag 2000) have pointed out that socioeconomic factors may have a somewhat lesser impact on acceptability than do attitudinal factors. In certain occasions, the latter may be rather determined by features scarcely analyzed in the literature, such as the quality of the alternative free road, if available, and regional differences on toll roads within the same nation. In this respect, regional approaches to road transport have mainly focused on very few specific topics such as road safety (Tolon-Becerra et al. 2013; Eksler et al. 2008).

Spain can be considered a representative case of an interurban highway network asymmetrically distributed across regions. While a significant percentage of the high capacity network is tolled in certain territories, other areas are provided with free high quality roads. This heterogeneity has generated negative sentiments towards road charging in those regions especially enduring the burden of tolls. This fact makes Spain an interesting case to analyze potential differences in toll road users' attitudes across regions.

The aim of this paper is to establish a first approach to explore regional differences on road users' perceptions towards toll roads. Particularly, it seeks to identify potential differences on users' attitudes and willingness to pay (WTP) as a result of an asymmetrical distribution of toll roads across regions. Furthermore, the relationship between users' perceptions and their declared WTP is addressed. Based on a nationwide survey conducted in interurban toll roads in Spain, we develop both a binomial logit and a censored regression (tobit) model to explore users' perceptions and WTP. This research has some noteworthy aspects. To our knowledge, this is one of the few nationwide surveys - jointly 
with those ones developed for Norway in Odeck and Brathen (2008; Odeck and Kjerkreit 2010) - conducted in interurban toll roads already in operation. The network considered, with a total of $2264 \mathrm{~km}$, is also among the longest interurban toll road systems ever surveyed in the literature. Furthermore, the model specification we use includes some explanatory variables barely analyzed to measure users' perceptions towards toll roads, such as the quality of the free parallel road. This paper focuses just on perceptions and attitudes among road drivers. Consequently, potential influences coming from the existence of alternative modes (rail, air) have not been considered. Finally, the research covers an interesting case in the international context, given the marked heterogeneity of toll roads across regions in Spain.

This paper is organized as follows. After this introductory chapter, "Literature review" section summarizes the state of knowledge regarding users' perceptions towards tolls, and provides some brief insight about the history and main characteristics of the Spanish interurban toll network. "The Spanish toll road network" section outlines the methodology of this research. "Methodology" section makes a description of the survey conducted to road users. "The data: a nationwide survey in Spanish toll roads" section presents and discusses the results. Finally, "Choice modeling results and discussion" section sets out the main conclusions and points out further research.

Table 1 Overview of the influence of different socioeconomic parameters on attitudes towards tolls

\begin{tabular}{|c|c|c|c|c|c|}
\hline Author (year) & $\begin{array}{l}\text { Podgorski and } \\
\text { Kockelman (2006) }\end{array}$ & $\begin{array}{l}\text { Dill and } \\
\text { Weinstein } \\
(2007)\end{array}$ & $\begin{array}{l}\text { Odeck and } \\
\text { Brathen } \\
(2008)\end{array}$ & $\begin{array}{l}\text { Odeck and } \\
\text { Kjerkreit } \\
(2010)\end{array}$ & $\begin{array}{l}\text { Chen and } \\
\text { Wen (2014) }\end{array}$ \\
\hline Context & Texas residents & $\begin{array}{l}\text { California } \\
\text { residents }\end{array}$ & $\begin{array}{l}\text { Road users in } \\
\text { Norway }\end{array}$ & $\begin{array}{l}\text { Road users in } \\
\text { Norway }\end{array}$ & $\begin{array}{l}\text { Road users } \\
\text { in Taiwan }\end{array}$ \\
\hline \multicolumn{6}{|l|}{$\begin{array}{c}\text { Explanatory } \\
\text { variables } \\
\text { included }\end{array}$} \\
\hline Trip length & N.s.s. & N.s.s. & - & N.s.s. & - \\
\hline $\begin{array}{l}\text { Travel } \\
\text { frequency }\end{array}$ & - & - & - & - & - \\
\hline Age & N.s.s. & ++ & N.s.s. & ++ & \\
\hline Gender & S.s. & S.s. & & N.s.s. & \\
\hline Education & ++ & ++ & & & \\
\hline Employment & S.s. & & & & \\
\hline Income & & N.s.s. & N.s.s. & ++ & \\
\hline $\begin{array}{l}\text { Political } \\
\text { leaning }\end{array}$ & & S.s. & & & \\
\hline $\begin{array}{l}\text { Level of } \\
\text { information }\end{array}$ & & & ++ & ++ & \\
\hline Type of vehicle & & & S.s. & & \\
\hline Travel purpose & & & N.s.s. & & S.s. \\
\hline $\begin{array}{l}\text { Who pays the } \\
\text { toll }\end{array}$ & & & N.s.s. & & \\
\hline
\end{tabular}

++ Statistical positive influence; - statistical negative influence

S.s statistically significant differences, N.s.s. non statistically significant differences 


\section{Literature review}

Previous studies on attitudes towards tolls have mainly focused on urban contexts, with special attention to the implementation of congestion charging systems in city centers (Furst and Dieplinger 2014; Gehlert et al. 2011; Kottenhoff and Freij 2009; Gaunt et al. 2007). By contrast, the literature analyzing users' perceptions on interurban areas is limited and primarily deals with American High Occupancy/Toll (HOT) lanes, such as Zmud et al. (2007) and Golob (2001). The terms 'perceptions' and 'attitudes' have both been used in the literature as almost synonyms to address users' view towards tolls. These terms are different to users' behavior, which reflects the choice actually followed by the respondents.

The acceptability of toll road pricing constitutes a complex matter that can be approached in a number of ways (Di Ciommo et al. 2013). Previous research studies in this field have analyzed the influence of socioeconomic factors (age, income, trip purpose, etc.) on users' perceptions towards tolls. The results of these studies are useful to target specific user market segments as well as predict future behavior of citizens. Nevertheless, they have not generally led to conclusive and coincident results about the influence of these variables on users' attitudes (Odeck and Kjerkreit 2010; Gehlert et al. 2011), as can be seen in Table 1 .

In this respect, some authors (Rienstra et al. 1999; Schade and Schlag 2000) have pointed out that socioeconomic factors may have a somewhat lesser impact on acceptability than do attitudinal factors. The latter may be determined by aspects such as the use of toll revenues (Schuitema and Steg 2008; Jaensiriak et al. 2005), the perceived fairness of charges (Bonsall et al. 2007; Schade and Baum 2007), existing community values or political leanings (Yusuf et al. 2014). All these factors can lead to regional differences on users' perceptions towards tolls, especially when charging conditions greatly vary across territories within the same nation.

Previous research studies addressing regional differences on road transport are scarce and mainly limited to analyze specific topics such as road safety (Tolon-Becerra et al. 2013; Eksler et al. 2008; Lassarre and Thomas 2005). Regarding acceptability towards road charges, only differences between residents in urban and rural areas have been addressed. According to Podgorski and Kockelman (2006), rural areas in Texas are more supportive for tolling when compared to urban contexts, likely because residents might be thinking of tolls not applied to roads in their areas. Also focusing in Texas, Kockelman et al. (2009) identified regional differences in terms of supporting different proposed congestion pricing policies. In the same line, the study by Dill and Weinstein (2007) in California found more support for tolling in rural or smaller urban areas. As can be noticed, these papers did not specifically focus on users' attitudes but on public perceptions in general.

For the case of Europe, the research on users' acceptability in the Norwegian toll network by Odeck and Brathen (2008 and Odeck and Kjerkreit 2010) can be considered the most relevant study, and also the only study addressing users' attitudes towards tolls nationwide. These authors underlined the importance of the level of information supplied to users prior to the implementation of road charging. With regard to Spain, no previous studies have been undertaken specifically to investigate users' perceptions towards toll roads.

On the other hand, literature regarding WTP in toll roads is extensive and typically focuses on managed lanes. A comprehensive review of the existing research can be found in Li et al. (2010). Many of the previous studies have addressed behavioral and travel 
characteristics influencing the value of time (VOT) (Rose and Hensher 2014; Burris et al. 2012; Amador et al. 2005). However, to our knowledge no effort has been made to analyze potential differences in WTP across regions. In Spain, Asensio and Matas (2008) and Álvarez et al. (2007) calculated the VOT in specific road corridors made up of a toll motorway and a free parallel road, but they did not make a nationwide analysis.

This paper aims to contribute to the existing literature in the following aspects. First, along with the studies conducted by Odeck and Kjerkreit (2010) in Norway, to our knowledge, this is one of the few nationwide surveys that analyze users' attitudes in interurban toll roads already in operation. Second, it constitutes a first insight concerning regional differences on users' attitudes and WTP caused by an asymmetrical road transport policy. Finally, we include variables barely used in previous studies to explain users' perceptions towards tolls, such as the quality of the free alternative road.

\section{The Spanish toll road network}

With a total of $16,582 \mathrm{~km}$, Spain has currently one of the longest high capacity road networks within Europe. Given the scarcity of quality roads in the nation until the mid1960s, a great effort was made over the last decades to build an extensive road network to promote economic growth and territorial cohesion among regions. As of 2013 toll road concessions were $18.2 \%$ of the high capacity network currently in operation (Ministerio de Fomento 2014), what also makes Spain one of the longest national tolled networks in the world.

Since the early 1970s, more than $3000 \mathrm{~km}$ of toll highway concessions have been put in operation (Matas et al. 2012). Nevertheless, Spanish toll roads are far from constituting a homogeneous network throughout the country. They were built in different periods, and are asymmetrically distributed over the territory. According to Vassallo et al. (2012), three different periods can be identified in the development of the road network in Spain:

- First period (1962-1975): Despite the aim of the government to provide the nation with a modern high capacity network, the budgetary resources were not enough to finance the program through public funds. In order to develop these high investment road projects, several toll highways were granted by the government to private concessionaires. The toll highways built during this period were mainly located in the most industrialized regions such as Catalonia, the Basque Country, Valencia, etc.

- Second period (1975-1995): The petroleum crisis in the 1970s destabilized the Spanish economy and postponed further extensions of the high capacity network. Later, the socialist government elected in 1982, which was politically opposed to road charging, promoted new road projects in the country fully financed through the public budget. The program built free highways, many of them connecting Madrid with the most important Spanish cities. The new program aimed at alleviating the deficit of road infrastructure in less developed regions, not served in the previous period.

- Third period (1996-2008): The need to contain the public deficit, as a prerequisite for joining the Eurozone, moved the central government towards using again the toll concession approach to build new roads. New projects primarily aimed at tackling the increasing road congestion near the city of Madrid, by promoting 5 toll roads parallel to the existing free radial highways. New concessions awarded in this period followed different approaches, not always based on road user charging, such as shadow tolls, availability payment mechanisms, etc. 
Consequently, the current situation in Spain is a tolled network asymmetrically located throughout the country. As can be seen in Table 2 and Fig. 1, great contrasts can be found in the Spanish high capacity network. While regions such as Catalonia, Valencia or Galicia have an extensive tolled network (above $300 \mathrm{~km}$ ), other territories such as Extremadura, Cantabria or Asturias have few, or even no, tolled kilometers. As we mentioned above, this is a result of the historical evolution of road policy in the country (see Fig. 1). At the beginning of the 1980s, high capacity roads in Spain were scarce and mainly comprised tolled sections concentrated in few regions. It was not until the 1990s and early 2000s that the high capacity network significantly increased and spread over most of the territory, generally financed through the public budget.

The current national toll network comprises two different types of toll roads. Firstly, few of the toll sections are tunnels, where a fixed toll is charged for crossing them. In terms of unitary values, toll rates for light vehicles in this type of infrastructure are quite expensive, lying from $0.143 \mathrm{Euro} / \mathrm{km}$ (Eje Aeropuerto tunnel) to $0.49 \mathrm{Euro} / \mathrm{km}$ (Artxanda tunnels). However, the vast majority of the toll network surveyed is made up of interurban road stretches $(99.6 \%$ of tolled $\mathrm{km}$ ), where users are charged per $\mathrm{km}$ driven. Toll rates within this group are lower - they range between 0.07 and 0.10 Euro/km for light vehicles-, and fairly homogeneous over the territory. Furthermore, tolls in Spain vary across

Table 2 Evolution of the interurban high capacity and toll road network in Spanish regions (1990-2010)

\begin{tabular}{|c|c|c|c|c|c|c|c|}
\hline \multirow[t]{2}{*}{ Region } & \multirow{2}{*}{$\begin{array}{l}\text { Surface } \\
\left(10^{3} \mathrm{~km}^{2}\right)\end{array}$} & \multicolumn{3}{|l|}{1990} & \multicolumn{3}{|l|}{2010} \\
\hline & & $\begin{array}{l}\text { High capacity } \\
\text { network }(\mathrm{km})\end{array}$ & $\begin{array}{l}\% \\
\text { Tolled }\end{array}$ & $\begin{array}{l}\text { Tolled } \\
\text { network } \\
(\mathrm{km})\end{array}$ & $\begin{array}{l}\text { High capacity } \\
\text { network }(\mathrm{km})\end{array}$ & $\begin{array}{l}\% \\
\text { Tolled }\end{array}$ & $\begin{array}{l}\text { Tolled } \\
\text { network } \\
(\mathrm{km})\end{array}$ \\
\hline Andalusia & 87.6 & 726 & 24.2 & 176 & 2642 & 9.1 & 241 \\
\hline Aragon & 47.7 & 330 & 58.2 & 192 & 781 & 20.1 & 157 \\
\hline Asturias & 10.6 & 80 & 76.3 & 61 & 408 & 5.4 & 22 \\
\hline $\begin{array}{l}\text { Balearic } \\
\text { Islands }\end{array}$ & 4.9 & 42 & 0.0 & 0 & 183 & 0.0 & 0 \\
\hline $\begin{array}{l}\text { Basque } \\
\text { Country }\end{array}$ & 7.2 & 359 & 62.1 & 223 & 598 & 41.5 & 248 \\
\hline $\begin{array}{l}\text { Canary } \\
\text { Islands }\end{array}$ & 7.4 & 198 & 0.0 & 0 & 308 & 0.0 & 0 \\
\hline Cantabria & 5.3 & 42 & 57.1 & 24 & 220 & 0.0 & 0 \\
\hline $\begin{array}{c}\text { Castilla-La } \\
\text { Mancha }\end{array}$ & 79.4 & 435 & 0.0 & 0 & 1809 & 13.2 & 239 \\
\hline $\begin{array}{l}\text { Castilla y } \\
\text { León }\end{array}$ & 94.2 & 501 & 41.3 & 207 & 2303 & 11.9 & 275 \\
\hline Catalonia & 32.1 & 838 & 68.4 & 573 & 1336 & 47.2 & 631 \\
\hline Extremadura & 41.6 & 17 & 0.0 & 0 & 744 & 0.0 & 0 \\
\hline Galicia & 29.6 & 141 & 83.7 & 118 & 1055 & 31.1 & 328 \\
\hline Madrid & 8.0 & 472 & 20.1 & 95 & 973 & 14.9 & 145 \\
\hline Murcia & 11.3 & 82 & 14.6 & 12 & 630 & 18.3 & 115 \\
\hline Navarra & 10.4 & 172 & 88.4 & 152 & 380 & 36.6 & 139 \\
\hline La Rioja & 5.0 & 129 & 91.5 & 118 & 165 & 72.1 & 119 \\
\hline Valencia & 23.2 & 561 & 68.6 & 385 & 1427 & 25.7 & 367 \\
\hline
\end{tabular}



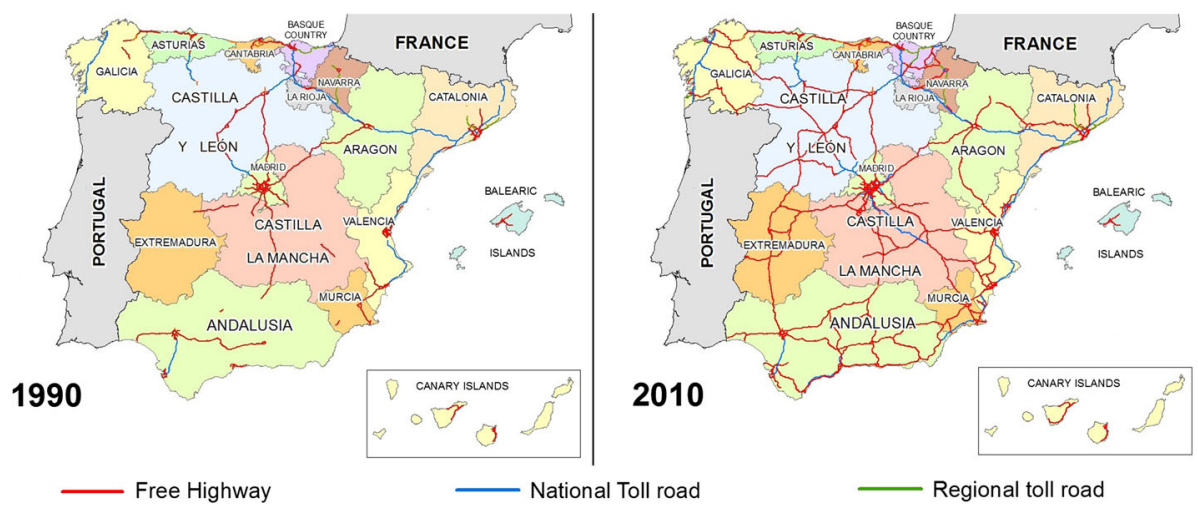

Fig. 1 Evolution of the interurban high capacity network in Spain (1990-2010)

vehicle types, with toll rates applied to heavy vehicles being around $50 \%$ higher than to light vehicles.

The regional asymmetry of the tolled network has been one of the reasons why people in certain regions have a sentiment of unfairness for enduring the burden of tolls. While drivers in Catalonia or Valencia have been paying tolls for decades, regions such as Castilla y León, Castilla-La Mancha or Andalusia have been provided with many free high capacity roads in the last 20 years (see Table 2). Territorial inequity in this respect is an issue repeatedly claimed and proposed in the political agenda by nationalist parties in regions such as Catalonia. Furthermore, social movements and associations have recently appeared at the regional level to coordinate protests and actions towards tolls, claiming for undergoing charging unfairness compared to the rest of Spaniards. This is the case of the so-called No vull pagar (in Catalan, "not wanting to pay") movement, present in the region of Catalonia and, to a lesser extent, in Valencia. Since 2012, this movement has occasionally organized protests in existing toll roads, encouraging drivers to cross tollgates without paying the toll and collapsing toll plazas for hours.

\section{Methodology}

In order to measure users' perceptions and WTP in interurban toll roads, we develop both a binomial logit and a censored regression model. The main characteristics of each statistical specification are summarized below. The predictors to calibrate these models were obtained from a survey that will be described in the following section.

\section{Binary choice models to measure users' perceptions}

The study employs binary choice models in order to measure the effect of certain socioeconomic factors and regional characteristics on users' attitudes and choices towards the use of toll roads. Particularly, respondents were asked in the survey (see "Methodology" section) whether they considered tolls as an appropriate mechanism to fund roads. This answer represented the dependent variable of the binary choice specification.

Binary choice models fall into the category of utility maximization models and they incorporate the micro-economic theories of consumer behavior and psychological choice 
behavior. Rational choice models assume that a person chooses the alternative with the higher utility (Ben-Akiva and Lerman 1995; Train 2003) among all the options available. The utility of each choice can be determined by a number of parameters related to both personal attributes of the individual $(\mathrm{X})$ and characteristics of the alternative itself $(\mathrm{S})$, which are described below (see "Methodology" section). Then the utility in the model is approached as follows:

$$
U_{i k}=f\left(X_{i k}, S_{i k}\right)
$$

where $\mathrm{U}_{\mathrm{ik}}$ is the utility gained by individual $\mathrm{k}$ for choosing alternative $\mathrm{i}$. $\mathrm{U}_{\mathrm{ik}}$ is considered a random variable and therefore consists of a sum of observed variables $\mathrm{V}_{\mathrm{ik}}$ - systematic or representative component of the utility - and random components $\varepsilon_{\mathrm{ik}}$ :

$$
U_{i k}=V_{i k}+\varepsilon_{i k}=\beta_{k} X_{i k}+\varepsilon_{i k}
$$

where is $X_{\mathrm{ik}}$ a vector of measurable characteristics that define utility, such as age, income, trip frequency, etc.; and $\beta_{\mathrm{k}}$ is a vector of parameters to be estimated (Louviere et al. 2006).

Economic theory assumes that the individual $\mathrm{k}$ will choose the option with the highest utility $\left(\mathrm{U}_{\mathrm{ik}}>\mathrm{U}_{\mathrm{jk}}\right)$. In the general form of a binary choice model, the probability that respondent $\mathrm{k}$ will choose alternative $\mathrm{i}$ is expressed as (Ben-Akiva et al. 1985):

$$
P_{i}=\frac{e^{V_{i k}}}{\sum_{j} e^{V_{i j}}}
$$

Then, the binary logistic regression predicts the logit of the odds ratio, $\mathrm{L}_{\mathrm{i}}$, given multiple explanatory variables $\mathrm{X}_{\mathrm{i}}$ (Peng and So 2002):

$$
L_{i}=\ln \frac{P_{i}}{1-P_{i}}=\alpha+\beta_{1} X_{1}+\beta_{2} X_{2} \ldots+\beta_{k} X_{k}
$$

As a result of this linearization process, the interpretation of the $\beta_{\mathrm{i}}$ coefficients is different compared to the ones from lineal regression models. In this case, the slope coefficient suggest that for a unit increase in a certain explanatory variable $X_{k}$, the weighted $\log$ of the odds in favor of a certain alternative $(Y=1)$ increases by $\mathrm{e}^{\beta \mathrm{k}}$. More appealingly, for a unit increase in a certain explanatory variable $\mathrm{X}_{\mathrm{k}}$, the odds ratio in favor of happening $\mathrm{Y}=1$ increases by $\mathrm{e}^{\beta \mathrm{k}}$.

Logit models adopt several distributional assumptions that differ with the usual regression models. Apart from the independence of the error terms and lack of multicollinearity problems in the sample, this specification assumes linearity of independent variables and logs of the odds ratio. Furthermore, the model resort to nonlinear estimating procedures using the method of maximum likelihood (Gujarati and Porter 2004), so a quite large sample size is required.

\section{Tobit specification to measure users' willingness to pay (WTP)}

Censored regression (tobit) models are employed in situations where the information on the dependent variable is available only for some observations (Gujarati and Porter 2004). This is the case of our survey, where users were asked about hypothetical situations in order to assess their WTP for specific scenarios (see "Methodology" section). In this respect, we found two types of users: those willing to use toll roads by paying a certain amount of money, and those users who will never use toll roads either because of income 
constraints or personal beliefs. In case we wanted to calculate a regression including the whole sample, we would find that no information would be available related to the WTP (from now on WTP) for the second group of users, so we have a censored sample.

In order to deal with the data from respondents not willing to use toll roads, we adopted a censored regression (tobit) model. According to Nolan (2002), the formulation of the underlying model would be:

$$
Y_{i}^{*}=\beta X_{i}+\varepsilon_{i}
$$

where $\mathrm{Y}^{*}$ is a continuous latent variable, $\mathrm{X}_{\mathrm{i}}$ is a matrix of explanatory variables, $\beta$ is a vector of coefficients to be estimated, and $\varepsilon_{\mathrm{i}}$ is a vector of normally distributed error terms. On the other hand, the observed variable $\left(\mathrm{Y}_{\mathrm{i}}\right)$ is defined by:

$$
\begin{cases}Y_{i}=Y_{i}^{*} & \text { if } Y_{i}^{*}>0 \\ Y_{i}=0 & \text { if } Y_{i}^{*} \lesssim 0\end{cases}
$$

It is important to highlight that the $\beta$ coefficients represent the effect of $\mathrm{X}_{\mathrm{i}}$ on the latent variable $\mathrm{Y}^{*}$, but not on the observed variable $\mathrm{Y}$, which is the difference with the linear regression model. As can be seen, the explanatory variables $\left(\mathrm{X}_{\mathrm{i}}\right)$ in the tobit model affect both the decision of individuals to choose/not to choose a specific alternative, as well as the intensity of their choice (Tsekeris and Dimitriou 2008). In contrast with logit models, tobit specifications adopt the same distributional assumptions as standard regression models so coefficients of these models should be interpreted in the usual way.

The combination of logit and tobit models for analyzing users' perceptions and WTP, respectively, constitutes a noteworthy methodological point of this research. In strict terms, it should be acknowledged that distinguishing attitudes from actual behavior and WTP can be better estimated through revealed preference (RP) Surveys. Nevertheless, a comparison between perceptions and stated-preference choices from real users of the toll network can also be a valuable approach to address such an issue. This procedure will allow a better understanding of the modeling results, which will lead to more efficient policy recommendations.

\section{The data: a nationwide survey in Spanish toll roads}

The data used in this research was collected from a nationwide survey developed in several Spanish interurban toll roads in 2010. It was addressed to users of interurban toll roads, both frequent and occasional ones, though also comprised potential users living close to the existing tolled infrastructure. The survey was conducted between October and November, 7-days a week with the aim to get a representative sample in terms of trip purpose. Depending on the type of user and the characteristics of the toll road, the data was collected from either phone questionnaires or personal interviews at service areas or petrol stations. We stratified the sample in order to achieve sufficient representation at the regional level. Further details about this survey can be found in Gomez and Vassallo (2014).

The paper is primarily aimed at identifying regional differences with regard to two main questions: users' perceptions towards toll roads and their WTP in interurban contexts. The questionnaire, divided into two main parts (see details in Appendix 1), was especially designed to that end. In the first part, drivers were asked about their socioeconomic characteristics (age, income, trip frequency, trip purpose, etc.), and also additional information regarding the toll road. These data mainly comprised the explanatory variables for 
the choice model described above. For the case of potential users, trip purpose was not asked since this subgroup in the sample never used toll roads before. Further comments about the explanatory variables in the questionnaire are included below.

The second part of the survey was related to drivers' attitudes regarding toll roads. In order to estimate general acceptability towards tolls, users were asked whether they considered tolls as an appropriate way to finance road infrastructure, in a similar way as in Odeck and Brathen (2008). This has been an approach previously adopted in the literature to account for users' perceptions towards road charges. ${ }^{1}$ Their answers at this point formed the dependent variable for the binary choice model detailed in subsection 3.1. Additionally, they reported their perceptions towards current toll rates. In this respect, it is important to note that it is a requirement that every toll concession in Spain has a free parallel road available in the corridor.

Finally, the questionnaire concluded with a simple stated-preference choice to measure users' WTP in different scenarios. Respondents were presented a corridor made up of a free road and a parallel toll highway which allows the driver to save travel time (TT). For a given 60- and 180-min trip in the free road, drivers were asked in open answer about the amount they would be willing to pay for specific TT savings $\left(\mathrm{TT}_{\text {sav }}\right)$ in the case of using the toll road. Therefore, respondents directly reported their WTP in different scenarios, what is particularly interesting in the case of frequent and occasional users. This information became the dependent variable for the tobit model described in subsection 3.2.

As this paper is mainly focused on identifying regional differences in users' attitudes, respondents in the sample were surveyed in a balanced way (see Table 3 below) from some of the regions with the largest toll road network. The survey focused on regions with mature toll roads, where user charging was implemented decades ago, and those ones with a more modern toll network. We also included some variability regarding the quality of the free parallel road (see Appendix 2). Catalonia, Madrid, Valencia, the Basque Country and Galicia were the cases ultimately selected for this research. Other regions with a significant length tolled (Andalusia, Castilla-La Mancha, Castilla y León) were not included because toll roads are not spread in a homogeneous way throughout the territory, but are concentrated on specific areas. This makes the analysis more difficult in these cases, since users' perceptions towards tolls may widely vary over the same region. A constant specific variable for each region was included in the model in order to identify potential regional differences and capture the influence of region-specific factors, such as the presence of an anti-toll atmosphere in certain territories.

The network included in the survey comprises all the interurban toll roads starting and/ or ending in the 5 regions selected. With a total of $2264 \mathrm{~km}$, this sample can be considered representative of the Spanish toll network, as it includes around $75 \%$ of total tolled $\mathrm{km}$ in the country. We would like to note that it is an extensive network when compared to other toll systems previously analyzed, both interurban toll networks (Odeck and Kjerkreit 2010; Zmud et al. 2007) or toll point facilities, such as bridges or tunnels (Yusuf et al. 2014; Gordon and Peters 2011).

The quality of the free parallel road available may constitute a significant explanatory factor to determine users' perceptions, since it increases the ability to avoid tolls. For the network surveyed, great asymmetry can be observed regarding this point (see Appendix 2). Tolled sections competing with free highways are numerous in regions such as Madrid, while in the Basque Country or Catalonia the alternative route is generally formed by a

1 In this research, we use the terms "users' perceptions" and "users' attitudes" interchangeably as it has usually been done in the literature. 
Table 3 Summary of characteristics in the sample

\begin{tabular}{|c|c|c|c|}
\hline Variable & Subgroup & Respondents & $\%$ Sample \\
\hline \multirow[t]{2}{*}{ Gender } & Male & 1645 & 51.3 \\
\hline & Female & 1559 & 48.7 \\
\hline \multirow[t]{5}{*}{ Age } & Under 24 & 173 & 5.4 \\
\hline & From 24 to 34 & 513 & 16.0 \\
\hline & From 35 to 49 & 1335 & 41.7 \\
\hline & From 50 to 64 & 900 & 28.1 \\
\hline & Above 64 & 283 & 8.8 \\
\hline \multirow[t]{5}{*}{ Income } & Under 20,000 Euro & 916 & 28.6 \\
\hline & From 20,000 to 30,000 Euro & 1116 & 34.8 \\
\hline & From 30,000 to 50,000 Euro & 462 & 14.4 \\
\hline & Above 50,000 Euro & 108 & 3.4 \\
\hline & Not responding & 602 & 18.8 \\
\hline \multirow[t]{5}{*}{ Type of vehicle } & Car & 2847 & 88.9 \\
\hline & Light van & 232 & 7.2 \\
\hline & Truck & 103 & 3.2 \\
\hline & Moto & 12 & 0.4 \\
\hline & Bus & 11 & 0.3 \\
\hline \multirow[t]{3}{*}{ Frequency/type of user } & Frequent & 2210 & 69.0 \\
\hline & Occasional & 705 & 22.0 \\
\hline & Potential & 288 & 9.0 \\
\hline \multirow[t]{6}{*}{ Trip purpose } & Commuting & 890 & 27.8 \\
\hline & Business & 349 & 10.9 \\
\hline & Weekend leisure & 783 & 24.4 \\
\hline & Holiday leisure & 562 & 17.5 \\
\hline & Other & 332 & 10.4 \\
\hline & Not included (potential users) & 288 & 9.0 \\
\hline \multirow[t]{5}{*}{ Region } & Catalonia & 640 & 20.0 \\
\hline & Madrid & 634 & 19.8 \\
\hline & Valencia & 652 & 20.3 \\
\hline & Basque country & 636 & 19.8 \\
\hline & Galicia & 642 & 20.0 \\
\hline \multirow[t]{2}{*}{ Quality of the alternative } & Conventional road & 2596 & 81.0 \\
\hline & Highway & 608 & 19.0 \\
\hline
\end{tabular}

conventional (two-lane) road, with poor characteristics. The research also measures the influence of additional variables on users' attitudes, such as unitary toll rates applied (taking into account the type of vehicle driven by the user) and the type of tolled infrastructure (interurban road/tunnel), since each one follows a different charging scheme. This research does not consider the potential influence of alternative transport modes (rail, air) on users' attitudes, since the survey is addressed to people who mostly travel by car.

Table 3 summarizes the main characteristics of the sample used for the two analyses conducted in this research: users' perceptions and WTP. A balanced proportion of men and women can be observed, as well as the distribution of respondents across regions. 
Furthermore, we identify a higher presence of people aged between 35 and 49, whose income typically lies below Euro 30,000, and a vast majority of cars (88.9\%) regarding the type of vehicle used. It is noticeable the high proportion of respondents $(18.8 \%)$ not reporting their income. Commuting $(27.8 \%)$ and weekend leisure $(24.4 \%)$ are the most common trip purposes in the sample, with a high proportion of respondents $(69.0 \%)$ making more than 8 trips per month (frequent users). These variables mainly comprise the explanatory parameters considered for this research, apart from some minor additions commented below.

\section{Choice modeling results and discussion}

This section reports the main findings from the analysis. Subsection 5.1 presents the results of modeling users' perceptions towards toll roads through a binomial logit specification. Estimates of the tobit model measuring drivers' WTP are displayed in Subsection 5.2.

\section{Users' perceptions towards interurban toll roads}

Before showing the estimates calculated through the binomial logit specification described in "The Spanish toll road network" section, some preliminary results are presented (see Table 4) for certain explanatory variables. Concerning the general perception on toll roads, the majority of respondents $(52.8 \%)$ were positive towards the application of tolls to finance road infrastructure. Nevertheless, this attitude does not seem to be homogeneous throughout the country when we disaggregate the results by regions.

Table 4 Users' perceptions towards toll roads and toll rates

\begin{tabular}{|c|c|c|c|c|c|}
\hline & \multicolumn{2}{|c|}{ Perception towards toll roads $(\%)$} & \multicolumn{3}{|c|}{ Perception on toll rates $(\%)$} \\
\hline & Positive & Negative & Cheap & Medium & Expensive \\
\hline Total sample & 52.8 & 47.2 & 0.9 & 13.0 & 86.1 \\
\hline \multicolumn{6}{|l|}{ Region } \\
\hline Catalonia & 41.4 & 58.6 & 0.2 & 5.9 & 93.9 \\
\hline Madrid & 65.1 & 34.9 & 1.8 & 26.4 & 71.8 \\
\hline Valencia & 48.5 & 51.5 & 0.5 & 13.4 & 86.1 \\
\hline Basque country & 54.5 & 45.5 & 0.1 & 10.2 & 89.7 \\
\hline Galicia & 54.9 & 45.1 & 1.1 & 10.2 & 88.7 \\
\hline \multicolumn{6}{|l|}{ Income } \\
\hline Below 20,000 Euro & 51.4 & 48.6 & 0.1 & 13.0 & 86.9 \\
\hline From 20,000 to 30,000 Euro & 53.7 & 46.3 & 0.5 & 11.9 & 87.6 \\
\hline From 30,000 to 50,000 Euro & 56.0 & 44.0 & 1.5 & 16.5 & 82.0 \\
\hline Above 50,000 Euro & 59.7 & 40.3 & 1.6 & 24.2 & 74.2 \\
\hline Not responding & 45.8 & 54.2 & 0.5 & 11.1 & 88.4 \\
\hline \multicolumn{6}{|l|}{ Quality alternative } \\
\hline Conventional road & 50.4 & 49.6 & 0.8 & 10.3 & 88.9 \\
\hline Highway & 63.1 & 36.9 & 1.4 & 24.6 & 74.0 \\
\hline
\end{tabular}

Preliminary results in percentage 
As can be seen, users' acceptability in Catalonia is low (41.4 \%), while in Madrid is particularly high $(65.1 \%)$ when compared to other regions in the sample. Furthermore, drivers' attitudes towards toll roads appear to be more positive as income increases. We can also observe that the level of acceptability is higher for those drivers using a toll road competing with a high quality alternative.

Regarding users' perceptions on toll rates, not modeled afterwards, we find that the majority of users $(86.1 \%)$ considered that toll rates applied are too high. Catalonia is the region with the most negative perception towards the level of toll rates (93.9\%), while Madrid is again the least negative $(71.8 \%)$. Given the fairly homogeneous toll rates applied throughout the country, the reason behind regional differences may be the asymmetrical density of toll roads and existence/absence of high quality free alternatives when compared to other territories. The network in some regions forces drivers, in a certain way, to use toll roads to save TT.

It can also be observed that, the higher the income (particularly above 50,000 Euro), the less negative users' attitudes towards toll rates. This is in line with other previous results referred to in the literature (Odeck and Kjerkreit 2010). Finally, focusing on the influence of the alternative road, we notice that users are less negative to toll rates when the free parallel road happens to be a highway.

In order to check the validity of these preliminary findings, a binomial logit specification has been calibrated. The model estimates the probability of being positive towards toll roads - that is, to consider tolls as an appropriate mechanism to fund roads - and measures the influence of different explanatory variables on this attitude. Before setting up the logit model, some tests for checking multicollinearity between the explanatory variables modeled were applied, showing no significant interactions.

The majority of explanatory variables in the model are categorical, so a base case needs to be chosen as a reference to better identify potential differences in users' perceptions (see Table 5). With regard to the region parameter, we have selected the Basque Country as the base case, since it seems to represent an intermediate position in terms of users' attitudes, given the preliminary results in Table 4 . Then, it allows us to approach whether users' perceptions in the rest of the regions, either positive (Madrid) or negative (Catalonia, Valencia), are statistically significant when compared to the base case.

In order to properly calculate the influence of each variable on users' perceptions, two different models have been calibrated. The first one (Model 1) includes the whole sample, and is mainly aimed at calculating how attitudes may vary depending on the type of user: potential, occasional and frequent. However, Model 1 is not able to estimate all the explanatory variables, since data related to e.g. trip purpose are not available for potential users. Consequently, a second logistic specification (Model 2) has been calculated for actual users - frequent and occasional ones- of the tolled network: In this case, it is possible to include two additional explanatory variables: toll rates and type of tolled infrastructure.

Table 5 includes empirical results from both models. As can be seen, coefficients remain fairly constant for those parameters simultaneously included in models 1 and 2 . The results confirm that, as pointed out in the literature (Rienstra et al. 1999; Schade and Schlag 2000), users' acceptability is often more influenced by attitudinal factors than by individual socioeconomic characteristics. Despite a more positive perception observed in the case of females, no statistically significant differences can be found throughout the subgroups established in terms of age, type of vehicle or income.

A less negative attitude towards toll roads is found with age, but the relationship is not statistically significant $(p$ value $>0.05$ ) neither for the variable as a whole nor for any of 
Table 5 Users' perceptions towards interurban toll roads: estimation results

\begin{tabular}{lllllll}
\hline Variables & \multicolumn{2}{l}{ Model 1: all respondents } & & \multicolumn{2}{l}{ Model 2: excluding potential } \\
\cline { 2 - 3 } \cline { 5 - 7 } & Coefficient & $\begin{array}{l}\text { Standard } \\
\text { error }\end{array}$ & p-value & & $\begin{array}{l}\text { Coefficient } \\
\text { Standard } \\
\text { error }\end{array}$ & p-value \\
\hline
\end{tabular}

Age

Under 25 (base case)

From 25 to 34

$-0.462 \quad 0.294$

$0.116-0.495$

0.309

0.110

From 34 to 49

$-0.496 \quad 0.281$

$0.077-0.512$

0.295

0.083

From 50 to 64

$-0.226 \quad 0.293$

$0.439-0.249$

0.309

0.420

Over 64

$-0.122$

0.970

$0.900-0.172$

0.861

Gender

Male (base case)

Female

0.279

0.079

0.000

0.264

0.084

0.002

Type of vehicle

Car (base case)

Light van

Truck

Moto

Bus

Region

Basque Country (base case)

Catalonia

Madrid

Valencia

Galicia

Type of user

Frequent user (base case)

Occasional user

Potential user

Quality of alternative

Conventional (base case)

Highway

0.331

0.129

0.010

0.412

0.153

0,007

Type of tolled infrastructure

Road (base case)

Tunnel

Toll rate

Income

Under 20,000 Euro (base case)

20,000 to 30,000 Euro

30,000 to 50,000 Euro

$\begin{array}{ll}0.118 & 0.124 \\ 0.156 & 0.161 \\ 0.278 & 0.287\end{array}$

0.340

0.078

0.131

0.554

Over 50,000 Euro

0.287

0.331

0.144

0.169

0.396

$0.334 \quad 0.233$

0.299

0.435

Trip purpose

Commuting (base case)

Business

0.254

0.136

0.061 
Table 5 continued

\begin{tabular}{|c|c|c|c|c|c|c|}
\hline \multirow[t]{2}{*}{ Variables } & \multicolumn{3}{|c|}{ Model 1: all respondents } & \multicolumn{3}{|c|}{ Model 2: excluding potential } \\
\hline & Coefficient & $\begin{array}{l}\text { Standard } \\
\text { error }\end{array}$ & p-value & Coefficient & $\begin{array}{l}\text { Standard } \\
\text { error }\end{array}$ & p-value \\
\hline Weekend leisure & & & & 0.164 & 0.109 & 0.134 \\
\hline Holiday leisure & & & & 0.084 & 0.121 & 0.487 \\
\hline Other & & & & -0.046 & 0.146 & 0.751 \\
\hline Constant & 0.881 & 0.256 & 0.001 & 0.545 & 0.248 & 0.028 \\
\hline$-2 \log$ likelihood & -4094 & & & -2805 & & \\
\hline$\rho^{2}$ & 0.066 & & & 0.087 & & \\
\hline No. of observations & 2601 & & & 2353 & & \\
\hline
\end{tabular}

the intervals established. Regarding the type of vehicle, no statistically different attitudes are found between truck and car users, despite the different percentage that tolls may represent in the total generalized cost for each case.

We can also see that the perception becomes more positive as the income increases, but a statistically significant influence cannot be concluded from this analysis, as in Dill and Weinstein (2007) and Odeck and Brathen (2008), among others. Frequency of trips does neither have an impact on users' perceptions towards toll roads, even though a more positive attitude, not statistically significant, is observed for potential users. This result, in line with Jaensiriak et al. (2005), may be caused by their expectancy of not using toll roads in the future and, consequently, not being affected by road pricing.

Regarding actual users of toll roads (Model 2), no differences are identified in terms of trip purpose when compared to the base case (commuting). The more positive perception for business trips, not far from being statistically significant, may be caused by the fact that in some cases the employer pays for this kind of trips. Finally, interurban trips related to leisure activities also show a higher level of acceptability, likely due to the less frequency of these trips.

In contrast with the limited influence of socioeconomic variables, users' perceptions towards toll roads in Spain seem to be more affected by attitudinal factors related to the specific context of each region. Even excluding the influence of the quality of the alternative road, we can observe that users from Valencia, and especially from Catalonia, significantly show a more negative perception towards toll roads. As mentioned above, this opinion can be explained at the light of the historical evolution of the road network in Spain and the anti-toll atmosphere in certain regions, which is amplified by nationalist parties. While regions such as Catalonia and Valencia took advantage of the early implementation of toll roads in the early 1970s, the subsequent development of free highways in the rest of the country in later years has made the former regions to feel unfairly treated. The current asymmetry of the Spanish toll network, whereby some users have to pay tolls while other ones can drive for free in high quality roads, seems to be the reason behind the negative perception in Catalonia and Valencia.

Despite having a high density of toll roads, no meaningful results are found in the case of Galicia, since this region shows a quite similar perception than users from the Basque Country. On the other hand, people in Madrid have a more positive attitude when compared to the base case. Although this result is not statistically significant, it appears to be strongly connected with the fact that toll roads in this region generally have a free quality 
Table 6 Users' willingness to pay: estimation results

\begin{tabular}{|c|c|c|c|c|c|c|}
\hline \multirow[t]{2}{*}{ Variables } & \multicolumn{3}{|c|}{ Model 1: all respondents } & \multicolumn{3}{|c|}{ Model 2: excluding potential } \\
\hline & Coefficient & $\begin{array}{l}\text { Standard } \\
\text { error }\end{array}$ & p-value & Coefficient & $\begin{array}{l}\text { Standard } \\
\text { error }\end{array}$ & p-value \\
\hline
\end{tabular}

Age

Under 25 (base case)

From 25 to 34

$-0.305 \quad 0.239$

0.201

$-0.310$

0.254

0.222

From 34 to 49

$-0.687$

0.220

0.001

$-0.754$

0.235

0.001

From 50 to 64

$\begin{array}{ll}-1.457 & 0.225\end{array}$

$0.000 \quad-1.697$

0.240

0.000

Over 64

$-1.853$

0.299

$0.000 \quad-2.204$

0.321

0.000

Gender

Male (base case)

Female

$-0.889$

0.105

$0.000-1.010$

0.114

0.000

Type of vehicle

Car (base case)

Light van

Truck

Moto

Bus

Region

Basque Country (base case)

Catalonia

Madrid

Valencia

Galicia

Type of user

Frequent user (base case)

Occasional user

Potential user

Quality of alternative

Conventional (base case)

$$
\text { Highway }
$$

Income

Under 20,000 Euro (base case)

20,000 to 30,000 Euro
30,000 to 50,000 Euro
Over 50,000 Euro

Over 50,000 Euro

$\begin{array}{ll}-0.715 & 0.200 \\ 0.025 & 0.288 \\ 0.029 & 0.784 \\ 0.321 & 0.922\end{array}$

$-0.118$

0.166

1.342

0.201

0.744

0.161

0.250

0.161

$-0.112$

0.122

$-0.750$

0.187

$0.359-0.202$

0.125

0.175

0.146

$\begin{array}{ll}0.000 & 1.314 \\ 0.000 & 0.726\end{array}$

0.213

0.000

$0.000-0.726$

0.171

0.000

$0.120 \quad 0.216$

0.171

0.205

Trip purpose

Commute (base case)

Business

Weekend leisure

Holiday leisure

Other

Travel time (TT)

$\begin{array}{llllll}-0.495 & 0.174 & 0.004 & -0.524 & 0.184 & 0.004 \\ & & & & & \\ 0.191 & 0.167 & 0.254 & 0.213 & 0.178 & 0.232 \\ -0.024 & 0.218 & 0.911 & 0.068 & 0.230 & 0.765 \\ 1.347 & 0.374 & 0.000 & 1.547 & 0.385 & 0.000\end{array}$

\subsection{6}

0.000

0.001

0.537

0.762 
Table 6 continued

\begin{tabular}{|c|c|c|c|c|c|c|}
\hline \multirow[t]{2}{*}{ Variables } & \multicolumn{3}{|c|}{ Model 1: all respondents } & \multicolumn{3}{|c|}{ Model 2: excluding potential } \\
\hline & Coefficient & $\begin{array}{l}\text { Standard } \\
\text { error }\end{array}$ & p-value & Coefficient & $\begin{array}{l}\text { Standard } \\
\text { error }\end{array}$ & p-value \\
\hline Travel time saving $\left(\mathrm{TT}_{\mathrm{sav}}\right)$ & 0.185 & 0.022 & 0.000 & 0.186 & 0.023 & 0.000 \\
\hline $\mathrm{TT} * \mathrm{TT}_{\mathrm{sav}}$ & -0.001 & 0.000 & 0.000 & 0.001 & 0.000 & 0.000 \\
\hline Constant & -3.211 & 0.567 & 0.000 & -3.415 & 0.604 & 0.000 \\
\hline$-2 \log$ likelihood & $-21,108$ & & & $-19,468$ & & \\
\hline No. of observations & 10,053 & & & 9190 & & \\
\hline
\end{tabular}

alternative. Unlike other regions, toll roads in Madrid are not perceived by the users as a burden, but an additional option to choose when the free parallel highway gets congested.

Finally, we can observe that users of toll roads competing with free highways show a more positive attitude — statistically significant— towards tolls. It seems reasonable given the fact that, in these situations, users dismiss the opportunity to drive by a free quality road, probably seeking further benefits offered by toll roads, such as TT reliability or congestion avoidance. No statistical influence is found for other explanatory variables, such as toll rates, probably because they remain fairly homogeneous throughout the network surveyed.

Regarding the goodness of fit of the estimated results, the models present a rho-squared coefficient of 0.066 and 0.088 , respectively, which may be considered acceptable for logit specifications according to Henser and Johnson (1981). Furthermore, the signs of the regression coefficients and their statistical and practical significance are in line with the expected results. This is actually important for binary regression models according to Gujarati and Porter (2004).

\section{Users' willingness to pay (WTP)}

Next, we analyze the second source of data obtained from the survey, referring to users' WTP according to the stated-preference choice they were presented. As previously done, we point out some preliminary findings before displaying the results estimated through a censored regression (tobit) specification.

For the whole sample (all respondents), Fig. 2 shows the distribution of users' WTP depending on different TT when driving in the free road, as well as TT savings $\left(\mathrm{TT}_{\text {sav }}\right)$ offered by the parallel toll road. We present the cumulative percentage of respondents in the sample (y-axis) willing to pay the toll rate reported in the $\mathrm{x}$-axis. The curves show a descending trend, since a lower percentage of the sample is willing to pay as the toll rate increases.

As seems reasonable, WTP tends to increase as TT and TT savings do. However, some results can be quite curious. The majority of the people surveyed with a positive perception towards tolls $(52.8 \%)$ do not seem to be in line with a high, or even moderate, WTP. As can be seen in the figure, for short trips (TT $=60 \mathrm{~min}$ ) around $40-50 \%$ of respondents are not willing to pay at all for saving time, and around 60-80\% are not willing to pay more than 1 euro. What seems to be even more surprising is that only around $50 \%$ of respondents are willing to pay more than 1 Euro for saving TT in interurban long trips $(\mathrm{TT}=180 \mathrm{~min})$. Although these results are not purely based on a revealed-preference 


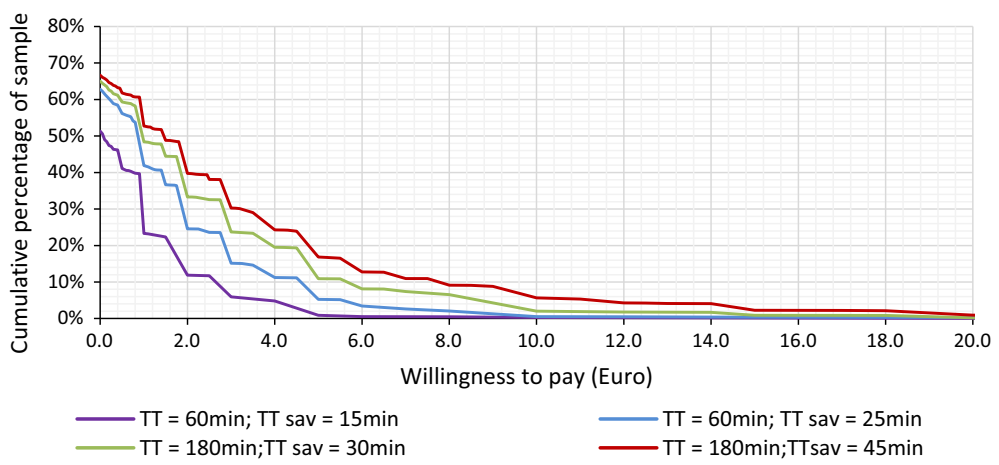

Fig. 2 Willingness to pay distribution in the sample depending on the travel time and travel time savings

analysis - but on a stated-preference model to actual users of toll roads-, they show the lack of connection that somehow exists between users' attitudes and real behavior in the field of road charging (Fifer et al. 2014; Burris et al. 2012).

Further relationships in the sample have been explored. WTP is generally lower for potential users when compared to actual users of toll roads (both frequent and occasional), especially in the case of short trips. Regarding the level of income, respondents earning above 50,000 Euro seem to have a higher WTP, particularly for long trips, while the rest of the sample present a fairly homogeneous behavior.

Figure 3 displays the distribution of WTP in the sample depending on the region selected. Findings are not conclusive, but some trends may be identified. If we exclude the results for low tolls (left-hand side of the figures), a quite homogeneous distribution is perceived in Catalonia, the Basque Country and Galicia. By contrast, WTP seems to be somewhat higher in the case of Madrid and Valencia.

Again, the validity of these preliminary findings is further explored through a censored regression (tobit) model (see Table 6). When compared to the previous logit specification (see Subsection 5.1) the explanatory variables toll rate and type of tolled infrastructure have been removed since they were not specifically determined in the stated-preference choice designed. On the other hand, the variable quality of the alternative here is not referring to the quality of the free road in the stated-preference case, but to the trip made by the respondent when she/he was surveyed. This allows us to explore whether statistical differences in users' WTP can be identified depending on the characteristics of the toll road she/he used. Furthermore, three additional explanatory variables were added to the choice model: TT in a certain scenario (TT), TT saving offered by the toll road $\left(\mathrm{TT}_{\mathrm{sav}}\right)$, and the interaction between these two parameters $\left(\mathrm{TT}^{*} \mathrm{TT}_{\mathrm{sav}}\right)$. As it happened in Subsection 5.1, two different models have been calculated due to the lack of data available for potential users with regard to trip purpose.

From the results of the tobit model in Table 6, some trends can be identified. It must be noted that, again, coefficient estimates remain fairly constant in models 1 and 2 . As Table 6 shows, WTP tends to increase as TT and TT savings provided by the toll road $\left(\mathrm{TT}_{\mathrm{sav}}\right)$ do. The results show that users are willing to pay, ceteris paribus, around 0.02 Euro for using the toll road as the TT increases $1 \mathrm{~min}$, and around 0.18 Euro as the $\mathrm{TT}_{\text {sav }}$ rises 1 min. Despite being statistically significant, the interaction term $\left(\mathrm{TT}^{*} \mathrm{TT}_{\text {sav }}\right)$ showed a very weak influence on WTP, because the value of the coefficient estimated was very close to zero. 

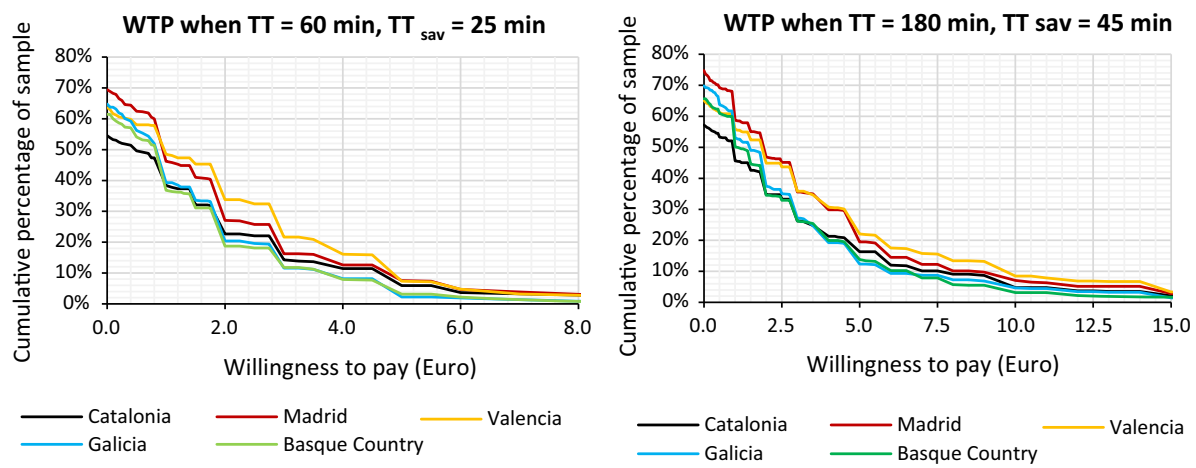

Fig. 3 Willingness to pay distribution in the sample depending on the region

With regard to the socioeconomic variables included in the model, we can observe that WTP significantly tends to decrease with age, particularly for respondents aged above 50 . As well as this, women are willing to pay between 0.8 and 1.0 Euro less than men. This behavior is inconsistent with women's more positive attitude towards tolls identified in the logit specification (see Table 5). No statistical differences can be identified regarding the type of vehicle.

Unlike results for users' perceptions towards toll roads, WTP sometimes vary with income and type of user. Respondents belonging to the interval with the highest income $(<50,000$ Euro) are statistically more willing to pay when compared to the base case, in line with previous research (Zmud et al. 2007; van den Berg 2014; Borjesson et al. 2012), according to which the VOT increases with income. With regard to the type of user, potential ones significantly show a lower WTP ( -0.7 Euro) when compared to actual users (frequent and occasional). Again, this contrasts with the higher acceptability by these types of users, probably because they do not expect to use toll roads very often. Additionally, WTP remarkably increases when the trip purpose is different from commuting. In the case of business trips, it should be caused by the fact that it is not always the employee, but in some cases the employer, who pays for the toll. Regarding leisure trips, the higher WTP may be influenced by the lower frequency of these kinds of trips, as pointed out by Cantos and Álvarez (2009).

Finally, we discuss the results concerning potential differences in users' WTP depending on the region and the quality of the free alternative. In this respect, a higher WTP is observed for respondents from Madrid (+1.3 Euro) and Valencia (+0.7 Euro), when compared to the base case. By contrast, respondents from the Basque Country, Galicia and Catalonia do not show statistically significant differences. If we compare these results with the estimates obtained for users' perceptions, two different cases come up. First, some regions such as Madrid and Catalonia have a comparatively high (low) WTP, which is in line with a general positive (negative) perception towards toll roads. By contrast, it is quite surprising that the WTP reported in Galicia and Valencia follows the opposite direction as the general perception towards tolls in these regions. Again, these results reinforce the idea that perceptions reported and WTP do not necessarily come together. They also show that a road transport policy asymmetrically developed over time does not need to clearly influence users' WTP, as it happens in the case of Valencia.

Finally, we can observe that those users driving in a toll road competing with a free highway are significantly more reluctant to pay ( -0.5 Euro) compared to toll roads in 
which the alternative is a conventional road. This result makes sense because the users of the toll road competing with a free highway do not value that much the benefits offered by the toll road given that the free alternative already provides high quality services. By contrast, the poor characteristics of conventional roads make drivers to be more willing to pay for using toll roads.

\section{Conclusions and further research}

In this paper we have developed both a binomial logit and a tobit model to explore users' attitudes and WTP on interurban toll roads. The analysis yielded some interesting conclusions.

The first conclusion is that a positive perception towards tolls is not always related to a higher WTP, but often to the low expectancy of using the tolled infrastructure. In this respect, it should be pointed out that, while acceptability may only reflect an overall sentiment of fairness towards tolls, WTP seems to be more closely related to the users' own experience and expected behavior. This idea may provide useful insights for future research objectives.

The second conclusion is that users' perceptions and WTP seem to be, in certain cases, only slightly determined by personal socioeconomic characteristics. This paper has made it clear that other variables barely explored in the literature, such as regional differences or the quality of the free alternative route, may play a more important role regarding toll roads perceptions.

The third conclusion shows that those regions comparatively suffering a higher burden of tolls or subjected to anti-toll campaigns generally have a more negative perception towards toll roads, but not necessarily a lower WTP. This is especially clear in cases such as Spain, with a heterogeneous toll implementation process across regions.

Finally, the fourth conclusion, strongly related to the third one, concerns the consequences of continually developing an asymmetrical road transport policy within the same nation. A coordinated and - as possible - homogeneous implementation of road transport policies within a nation is advisable in order to avoid that some regions perceive to be treated unfairly. A more balanced implementation across regions of pricing strategies and road accessibility provision can contribute to better distribute the burden of road financing, as well as to avoid negative perceptions in certain territories. Nevertheless, this fact needs to be complemented with further alternative analysis. Particularly, the consequences that changes in the current pricing policy may have on regional development and territorial cohesion within the same country are additional aspects to be taken into account.

From the results of this paper, some aspects can be pointed out for further research. First, the influence of attitudinal variables on users' choices and perceptions need to be explored more deeply, likely through a structural equation approach. Furthermore, differences on acceptability towards road charging across groups of respondents, i.e. across regions, should be analyzed in greater detail by adopting more suitable econometric specifications such as multilevel models. The influence of alternative transport modes may also be considered when analyzing users' perceptions on road interurban trips. Additionally, further efforts are needed to estimate differences between attitudes reported by users and their revealed behavior. Finally, a cross-comparison of users' perceptions in urban/ metropolitan and interurban toll roads would be useful to identify the issues to be improved regarding road charging policies in each context.

Acknowledgments The authors wish to thank the Spanish Ministry of Economy and Competitiveness (MINECO), which has funded the project "EU Support Mechanisms to promote Public Private Partnerships for financing TransEuropean Transport Infrastructure" [TRA 2012-36590]. 


\section{Appendix 1}

See Table 7.

Table 7 Variables measured and questions addressed in the survey

\begin{tabular}{|c|c|c|}
\hline Variable & $\begin{array}{l}\text { Question } \\
\text { addressed }\end{array}$ & Options provided \\
\hline \multicolumn{3}{|l|}{ Socioeconomic characteristics } \\
\hline Gender & & Male; Female \\
\hline Age & $\begin{array}{l}\text { Where do you } \\
\text { place your } \\
\text { age in the } \\
\text { following } \\
\text { intervals? }\end{array}$ & $\begin{array}{l}\text { Under 25; From } 25 \text { to } 34 \text {; From } 35 \text { to } 49 \text {; From } 50 \text { to } 64 \text {; } \\
\text { Above } 64\end{array}$ \\
\hline Income & $\begin{array}{l}\text { Where do you } \\
\text { put your } \\
\text { personal } \\
\text { income in } \\
\text { the } \\
\text { following } \\
\text { intervals? }\end{array}$ & $\begin{array}{l}\text { Under 20,000; From } 20,000 \text { to } 30,000 \text {; From } 30,000 \text { to } \\
\text { 50,000; Above } 50,000\end{array}$ \\
\hline Type of vehicle & & Car; Light van; Truck; Moto; Bus \\
\hline Region & & Catalonia; Madrid; Valencia; Basque Country; Galicia \\
\hline Frequency/type of user & $\begin{array}{l}\text { How often do } \\
\text { you use toll } \\
\text { roads, } \\
\text { considering } \\
\text { the } \\
\text { following } \\
\text { intervals? }\end{array}$ & $\begin{array}{l}\text { More than } 8 \text { trips per month (frequent user); Less than } 8 \\
\text { trips per month (occasional user); Never used it before } \\
\text { (potential user) }\end{array}$ \\
\hline $\begin{array}{l}\text { Trip purpose (only for } \\
\text { frequent and occasional } \\
\text { users) }\end{array}$ & $\begin{array}{l}\text { What is the } \\
\text { most } \\
\text { common } \\
\text { trip purpose } \\
\text { when you } \\
\text { use toll } \\
\text { roads? }\end{array}$ & $\begin{array}{l}\text { Commuting; Business/Work related activities; Weekend } \\
\text { leisure; Holiday leisure; Other }\end{array}$ \\
\hline
\end{tabular}

Characteristic of the toll road

Quality of the free alternative

Toll rate

Tunnel

Attitudes towards tolls

Perception towards toll roads

Conventional road; Highway

Expressed in Euro/km

Tunnel; interurban road

Do you think

Yes; No

that tolls are

an

appropriate

mechanism

to fund

roads? 
Table 7 continued

\begin{tabular}{|c|c|c|}
\hline Variable & $\begin{array}{l}\text { Question } \\
\text { addressed }\end{array}$ & Options provided \\
\hline Perception on toll rates & $\begin{array}{l}\text { In your } \\
\text { opinion, } \\
\text { current toll } \\
\text { rates are... }\end{array}$ & Expensive; Medium; Cheap \\
\hline Perception on time savings & $\begin{array}{l}\text { In your } \\
\text { opinion, } \\
\text { using toll } \\
\text { roads makes } \\
\text { you save... }\end{array}$ & $\begin{array}{l}\text { A considerable amount of travel time; Not so much travel } \\
\text { time; No travel time at all }\end{array}$ \\
\hline \multirow[t]{5}{*}{ Willingness to pay } & $\begin{array}{l}\text { Given a } \\
\text { certain } \\
\text { corridor } \\
\text { formed by a } \\
\text { free road } \\
\text { and a } \\
\text { parallel toll } \\
\text { road which } \\
\text { allows you } \\
\text { to save } \\
\text { time, how } \\
\text { much would } \\
\text { you pay for } \\
\text { using the } \\
\text { toll road } \\
\text { if...? }\end{array}$ & \\
\hline & $\begin{array}{l}\text { Travel time is } \\
60 \text { min \& } \\
\text { toll road } \\
\text { saves } \\
15 \mathrm{~min}\end{array}$ & Open answer (Euro) \\
\hline & $\begin{array}{l}\text { Travel time is } \\
60 \text { min \& } \\
\text { toll road } \\
\text { saves } \\
25 \mathrm{~min}\end{array}$ & Open answer (Euro) \\
\hline & $\begin{array}{l}\text { Travel time is } \\
180 \mathrm{~min} \& \\
\text { toll road } \\
\text { saves } \\
30 \mathrm{~min}\end{array}$ & Open answer (Euro) \\
\hline & $\begin{array}{l}\text { Travel time is } \\
180 \mathrm{~min} \& \\
\text { toll road } \\
\text { saves } \\
45 \mathrm{~min}\end{array}$ & Open answer (Euro) \\
\hline
\end{tabular}




\section{Appendix 2}

Table 8.

Table 8 Main characteristics of the toll roads included in the sample

\begin{tabular}{|c|c|c|c|c|c|c|}
\hline Region & Toll road & $\begin{array}{l}\text { Year } \\
\text { of } \\
\text { start }\end{array}$ & $\begin{array}{l}\text { Length } \\
(\mathrm{km})\end{array}$ & $\begin{array}{l}\text { Toll rate, } \\
\text { light vehicle } \\
\text { (Euro/km) }\end{array}$ & $\begin{array}{l}\text { Regions } \\
\text { crossed } \\
\text { by the toll } \\
\text { road }\end{array}$ & $\begin{array}{l}\text { High capacity } \\
\text { alternative road }\end{array}$ \\
\hline \multirow[t]{11}{*}{ Catalonia } & $\begin{array}{l}\text { Montmeló-La } \\
\text { Jonquera }\end{array}$ & 1972 & 135.6 & 0.089 & Catalonia & Partly $(3.0 \%)$ \\
\hline & Montmeló-Papiol & 1978 & 26.6 & 0.092 & Catalonia & No \\
\hline & Barcelona-Tarragona & 1975 & 96.6 & 0.089 & Catalonia & Partly $(9.7 \%)$ \\
\hline & $\begin{array}{l}\text { Zaragoza- } \\
\text { Mediterráneo }\end{array}$ & 1976 & 215.5 & 0.095 & $\begin{array}{c}\text { Catalonia, } \\
\text { Aragon }\end{array}$ & Partly $(6.6 \%)$ \\
\hline & Barcelona-Montmeló & 1972 & 14.2 & 0.100 & Catalonia & Yes \\
\hline & Montgat-Palafolls & 1969 & 43.1 & 0.087 & Catalonia & No \\
\hline & $\begin{array}{l}\text { Castelldefels-El } \\
\text { Vendrell }\end{array}$ & 1992 & 56.3 & 0.163 & Catalonia & No \\
\hline & San Cugat-Manresa & 1990 & 43.1 & 0.147 & Catalonia & No \\
\hline & Vallvidriera Tunnels & 1992 & 16.7 & 0.206 & Catalonia & No \\
\hline & Cadí Tunnel & 1986 & 29.7 & 0.392 & Catalonia & No \\
\hline & Tarragona-Valencia & 1978 & 225.3 & 0.096 & $\begin{array}{l}\text { Catalonia, } \\
\text { Valencia }\end{array}$ & Partly $(19.8 \%)$ \\
\hline \multirow[t]{7}{*}{ Madrid } & Madrid-Guadalajara & 2003 & 64.1 & 0.099 & $\begin{array}{c}\text { Madrid, Cast.- } \\
\text { La Mancha }\end{array}$ & Yes \\
\hline & Madrid-Arganda & 2003 & 33.1 & 0.096 & Madrid & Yes \\
\hline & Madrid-Ocaña & 2003 & 53.0 & 0.104 & $\begin{array}{l}\text { Madrid, Cast.- } \\
\text { La Mancha }\end{array}$ & Yes \\
\hline & Madrid-Navalcarnero & 2003 & 29.0 & 0.109 & Madrid & Yes \\
\hline & Eje Aeropuerto & 2005 & 8.8 & 0.143 & Madrid & Yes \\
\hline & Villalba-Adanero & 1977 & 69.6 & 0.144 & $\begin{array}{l}\text { Madrid, } \\
\text { Castilla y } \\
\text { León }\end{array}$ & No \\
\hline & Madrid-Toledo & 2006 & 60.0 & 0.092 & $\begin{array}{c}\text { Madrid, Cast.- } \\
\text { La Mancha }\end{array}$ & Yes \\
\hline \multirow[t]{4}{*}{ Valencia } & Tarragona-Valencia & 1978 & 225.3 & 0.096 & $\begin{array}{l}\text { Valencia, } \\
\text { Catalonia }\end{array}$ & Partly $(19.8 \%)$ \\
\hline & Valencia-Alicante & 1976 & 148.5 & 0.097 & Valencia & Partly $(9.2 \%)$ \\
\hline & $\begin{array}{l}\text { Circunvalación } \\
\text { Alicante }\end{array}$ & 2007 & 28.5 & 0.101 & Valencia & Yes \\
\hline & Alicante-Cartagena & 2001 & 76.6 & 0.061 & $\begin{array}{r}\text { Valencia, } \\
\text { Murcia }\end{array}$ & No \\
\hline
\end{tabular}


Table 8 continued

\begin{tabular}{|c|c|c|c|c|c|c|}
\hline Region & Toll road & $\begin{array}{l}\text { Year } \\
\text { of } \\
\text { start }\end{array}$ & $\begin{array}{l}\text { Length } \\
(\mathrm{km})\end{array}$ & $\begin{array}{l}\text { Toll rate, } \\
\text { light vehicle } \\
\text { (Euro/km) }\end{array}$ & $\begin{array}{l}\text { Regions } \\
\text { crossed } \\
\text { by the toll } \\
\text { road }\end{array}$ & $\begin{array}{l}\text { High capacity } \\
\text { alternative road }\end{array}$ \\
\hline \multirow[t]{5}{*}{$\begin{array}{l}\text { Basque } \\
\text { Country }\end{array}$} & Artxanda Tunnels & 2003 & 3.0 & 0.492 & $\begin{array}{l}\text { Basque } \\
\text { Country }\end{array}$ & No \\
\hline & Bilbao-Ermua & 1976 & 36.2 & 0.087 & $\begin{array}{l}\text { Basque } \\
\text { Country }\end{array}$ & Partly $(5.3 \%)$ \\
\hline & Ermua-Behobia & 1976 & 87.6 & 0.107 & $\begin{array}{l}\text { Basque } \\
\text { Country }\end{array}$ & No \\
\hline & Maltzaga-Arrasate & 2003 & 35.6 & 0.107 & $\begin{array}{l}\text { Basque } \\
\text { Country }\end{array}$ & No \\
\hline & Bilbao-Zaragoza & 1978 & 294.4 & 0.092 & $\begin{array}{l}\text { Basque } \\
\text { Country, La } \\
\text { Rioja, } \\
\text { Aragon }\end{array}$ & Partly (18.0\%) \\
\hline \multirow[t]{4}{*}{ Galicia } & $\begin{array}{c}\text { Ferrol-Front. } \\
\text { Portuguesa }\end{array}$ & 1979 & 218.9 & 0.089 & Galicia & Partly $(14.4 \%)$ \\
\hline & $\begin{array}{l}\text { Santiago-Alto Sto. } \\
\text { Domingo }\end{array}$ & 2003 & 56.6 & 0.094 & Galicia & No \\
\hline & La Coruña-Carballo & 1998 & 32.6 & 0.068 & Galicia & No \\
\hline & Puxeiros-Val Miñor & 1999 & 25.2 & 0.060 & Galicia & No \\
\hline
\end{tabular}

\section{References}

Álvarez, Ó., Cantos, P., García, L.: The value of time and transport policies in a parallel road network. Transp. Policy 14, 366-376 (2007)

Amador, F.J., Gonzalez, R.M., Ortuzar, J.D.: Preference heterogeneity and willingness to pay for travel time savings. Transportation 32(6), 627647 (2005)

Asensio, J., Matas, A.: Commuters' valuation of travel time variability. Transp. Res. Part E 44, 1074-1085 (2008)

Ben-Akiva, M.E., Lerman, S.R.: Discrete Choice Analysis: theory and Application to Travel Demand. MIT Press, Cambridge (1995)

van den Berg, V.: Coarse tolling with heterogeneous preferences. Transp Res Part B 64, 1-23 (2014)

Bonsall, P., Shires, J., Maule, J., Matthews, B., Beale, J.: Responses to complex pricing signals: theory, evidence and implications for road pricing. Transp. Res. Part A 41, 672-683 (2007)

Borjesson, M., Fosgerau, M., Algers, S.: On the income elasticity of the value of travel time. Transp Res Part A 46, 368-377 (2012)

Burris, M., Nelson, S., Kelly, P., Gupta, P., Cho, Y.: Willingness to pay for high-occupancy toll lanes. Empirical analysis from I-15 and I-394. Transp. Res. Rec. 2297, 47-55 (2012)

Cantos, P., Álvarez, Ó.: El valor del tiempo con congestión: El caso de la Radial-3. Rev. de Econ. Apl. 51, 55-80 (2009)

Chen, D.J., Wen, Y.H.: Effects of freeway mileage-based toll scheme on the short-range driver's route choice behavior. J. Urban Plan. Dev. 140, 04013012 (2014)

Di Ciommo, F., Monzón, A., Fernandez-Heredia, A.: Improving the analysis of road pricing acceptability surveys by using hybrid models. Transp. Res. Part A 49, 302-316 (2013)

Dill, J., Weinstein, A.: How to pay for transportation? A survey of public preferences in California. Transp. Policy 14, 346-356 (2007)

Eksler, V., Lassarre, S., Thomas, I.: Regional analysis of road mortality in Europe. Public Health 122(9), 826-837 (2008) 
Fifer, S., Rose, J., Greaves, S.: Hypothetical bias in stated choice experiments: is it a problem? And if so, how do we deal with it? Transp. Res. Part A 61, 164-177 (2014)

Furst, E.W.M., Dieplinger, M.: The acceptability of road pricing in Vienna: the preference patterns of car drivers. Transportation 41(4), 765-784 (2014)

Gaunt, M., Rye, T., Allen, S.: Public acceptability of road user charging: the case of Edinburgh and the 2005 referendum. Transp. Rev. 27, 85-102 (2007)

Gehlert, T., Kramer, C., Nielsen, O.A., Schlag, B.: Socioeconomic differences in public acceptability and car use adaptation towards urban road pricing. Transp. Policy 18, 685-694 (2011)

Golob, T.F.: Joint models of attitudes and behavior in evaluation of the San Diego I-15 congestion pricing project. Transp. Res. Part A 35, 495-514 (2001)

Gomez, J., Vassallo, J.M.: Percepción de los usuarios potenciales, ocasionales y frecuentes a las autopistas de peaje españolas. Working Paper. Universidad Politécnica de Madrid (2014)

Gordon, C., Peters, J.: Measuring toll burdens applying lorenz curves to a detailed data set of users of metropolitan transportation administration bridges in New York City. Transp. Res. Rec. 2221, 96-103 (2011)

Gujarati, D., Porter, D.C.: Basic Econometrics, 4th edn. The Mc Graw-Hill Companies, New York (2004)

Henser, D.A., Johnson, L.W.: Applied Discrete Choice Modeling. Croom Helm, London (1981)

Jaensiriak, S., Wardman, M., May, D.: Explaining variations in public acceptability of road pricing schemes. J. Transp. Econ. Policy 39, 127-153 (2005)

Kockelman, K.M., Podgorski, K.V., Bina, M., Gadda, S.: Public perceptions of pricing existing roads and other transportation policies: the Texas perspective. J. Transp. Res. Forum 48, 19-38 (2009)

Kottenhoff, K., Freij, K.B.: The role of public transport for feasibility and acceptability of congestion charging - the case of Stockholm. Transp. Res. Part A 43, 297-305 (2009)

Lassarre, S., Thomas, I.: Exploring road mortality in Europe: national versus regional realities. J. R. Stat. Soc. Ser. A 168, 127-144 (2005)

Li, Z., Hensher, D.A., Rose, J.M.: Willingness to pay for travel time reliability in passenger transport: a review and some empirical evidence. Transp. Res. Part E 46, 384-403 (2010)

Louviere, J.J., Hensher, D.A., Swait, J.D.: Stated Choice Methods: Analysis and Applications.Cambridge University Press, Cambridge (2006)

Matas, A., Raymond, J.L., Ruiz, A.: Traffic forecasts under uncertainty and capacity constraints. Transportation 39, 1-17 (2012)

Matas, A., Raymond, J.L.: Demand elasticity on tolled motorways. J Transp. Stat. 6(2/3), 91-105 (2003)

de Fomento, Ministerio: Anuario Estadístico 2013. Centro de Publicaciones, Secretaría General Técnica (2014)

Nolan, A.: The determinants of urban households' transport decisions: a microeconometric study using irish data. R. Econ. Soc. Annu. Conf. 2002, 1-42 (2002)

Odeck, J., Kjerkreit, A.: Evidence on users' attitudes towards road user charges-A cross sectional survey of six Norwegian toll schemes. Transp. Policy 17, 349-358 (2010)

Odeck, J., Brathen, S.: Travel demand elasticities and users attitudes: a case study of Norwegian toll projects. Transp. Res. Part A 42, 77-94 (2008)

Peng, C.Y., So, T.S.H.: Logistic regression analysis: a premier. Underst. Stat. 1, 31-70 (2002)

Podgorski, K.V., Kockelman, K.M.: Public perceptions of toll roads: a survey of the Texas perspective. Transp. Res. Part A 40, 888-902 (2006)

Rienstra, S.A., Rietveld, P., Verhoef, E.T.: The social support for policy measures in passenger transport. a statistical analysis for The Netherlands. Transp. Res. Part D 4, 181-200 (1999)

Rose, J.M., Hensher, D.A.: Tollroads are only part of the overall trip: the error of our ways in past willingness to pay. Transportation 41(4), 819-837 (2014)

Schade, J., Baum, M.: Reactance of acceptance? Reactions towards the introduction of road pricing. Transp. Res. Part A 41, 41-48 (2007)

Schade, J., Schlag, B.: Acceptability of Urban Transport Pricing. Research Report 72, Government Institute for Economic Research, Helsinki (2000)

Schuitema, G., Steg, L.: The role of revenue use in the acceptability of transport pricing policies. Transp. Res. Part F 11, 221-231 (2008)

Tolon-Becerra, A., Lastra-Bravo, X., Flores-Parra, I.: National and regional analysis of road accidents in Spain. Traffic Inj. Prev. 14(5), 486-495 (2013)

Train, K.: Discrete Choice Methods with Simulation. Cambridge University Press, Cambridge (2003)

Tsekeris, T., Dimitriou, L.: Modeling participation and consumption in the greek interurban public transportation market. J. Public Transp. 11, 85-104 (2008)

Vassallo, J.M., Ortega, A., Baeza, M.Á.: Impact of the economic recession on toll highway concessions in Spain. J. Manag. Eng. 28, 398-406 (2012) 
Yusuf, J.E., O'Connell, L., Anuar, K.A.: For whom the tunnel be tolled: a four-factor model for explaining willingness-to-pay tolls. Transp. Res. Part A 59, 13-21 (2014)

Zmud, J., Bradley, M., Douma, F.: Attitudes and willingness to pay for tolled facilities-a panel survey evaluation. Transp. Res. Rec. 1996, 85 (2007)

Juan Gomez is a Ph.D. Candidate at the Civil Engineering School (UPM). His research activities focus on transport economics, road charging, electronic toll collection and transport modelling. He has published in prestigious journals and participated in consultancy projects in the transport area.

Anestis Papanikolaou is a data scientist (Barcelona Graduate School of Economics) and Ph.D. Candidate at the School of Rural and Surveying Engineering (AUTH). His research interests are in the intersection of transport economics, data mining/machine learning and network theory.

José Manuel Vassallo is Associate Professor at the Civil Engineering School (UPM). His research activity mainly focuses on transportation management and financing, infrastructure regulation, and public-private partnerships. He has published 6 books and more than 30 papers in prestigious journals. 